\section{Performance of Containerized and Bare- root Transplants with Soil Fumigants for Florida Strawberry Production}

\author{
James P. Gilreath ${ }^{1}$, Bielinski M. Santos ${ }^{1}$, Joseph W. Noling ${ }^{2}$, \\ Salvadore J. Locascio ${ }^{3}$, Donald W. Dickson ${ }^{4}$, Erin N. Rosskopf ${ }^{5}$, \\ and Steven M. Olson ${ }^{6}$
}

ADDITIONAL INDEX WORDs. Fragaria xananassa, ring nematode, nutsedge, methyl bromide, 1,3-dichloropropene, chloropicrin, metam, napropamide

Summary. Field studies were conducted in three Florida locations (Bradenton, Gainesville, and Quincy) during 1998-99 and 1999-2000 to: 1) compare the performance of two transplant systems under diverse $\mathrm{MBr}$ alternative programs in 'Chandler' strawberry (Fragaria xananassa), and 2) determine the efficacy of these treatments on soilborne pest control in strawberry. Fumigant treatments were: 1) nonfumigated control, 2) methyl bromide plus chloropicrin $(\mathrm{MBr}+\mathrm{Pic})$ at a rate of $350 \mathrm{lb} / \mathrm{acre}, 3) \mathrm{Pic}$ at $300 \mathrm{lb} /$ acre and napropamide at $4 \mathrm{lb} /$ acre, 4) 1,3-dichloropropene (1,3-D) plus Pic at 35 gal/acre and napropamide at 4 $\mathrm{lb} /$ acre, 5) metam sodium (MNa) at $60 \mathrm{gal} /$ acre and napropamide at $4 \mathrm{lb} / \mathrm{acre}$, and 6) MNa followed by 1,3-D at 60 and $12 \mathrm{gal} / \mathrm{acre}$ and napropamide at 4 $\mathrm{lb} / \mathrm{acre}$, respectively. Strawberry transplants were either bare-root or containerized plugs. There were no significant fumigant by transplant type interactions for strawberry plant vigor and root weight per plant, whereas ring nematode (Criconema spp.) and nutsedge (Cyperus rotundus and C. esculentus) populations, and total marketable fruit weight were only influenced by fumigant application. The nonfumigated plots had the lowest strawberry plant vigor and root weight per plant in all three locations. In most cases, plant vigor and root biomass per plant increased as a response to any fumigant application. With regard to the transplant type, bare-root transplants had similar plant vigor as plugs in two of the three locations. Fumigation improved nutsedge and ring nematode control. All fumigants had higher early and total marketable yield than the nonfumigated control, whereas transplant type had no effect on total fruit weight.

$\mathrm{D}$ uring 2004, U.S. strawberry production represented more than $\$ 1.47$ billion in gross value [U.S. Department of Agriculture (USDA), 2005]. Florida is the second leading state in the U.S. in planted area and value with 7100 acres and $\$ 178$ million, respectively (USDA, 2005).

${ }^{1}$ Professor and Assistant Professor of Horticulture, respectively, GulfCoast Research and Education Center, University of Florida, Wimauma, FL 33598; e-mail: bmsantos@ufl.edu.

${ }^{2}$ Professor of Nematology, Citrus Research and Education Center, University of Florida, Lake Alfred, FL 33850.

${ }^{3}$ Professor Emeritus of Horticulture, Horticultural Sciences Department, University of Florida, Gainesville, FL 32611 .

${ }^{4}$ Professor of Nematology, Entomology and Nematology Department, University of Florida, Gainesville, FL 32611

${ }^{5}$ Microbiologist, Agricultural Research Service, United States Department of Agriculture, Ft. Pierce, FL 34945

${ }^{6}$ Professor of Horticulture, North Florida Research and Education Center, University of Florida, Quincy, FL 32351 .
Strawberry harvest in Florida occurs between December and March, when other growing states are not planting the crop, allowing local growers to take advantage of high market prices during winter and early spring.

Traditionally, strawberry is transplanted in polyethylene-mulched beds with drip irrigation and the soil is treated with $\mathrm{MBr}+$ Pic to control soilborne diseases, nematodes, and weeds
(Simonne et al., 2003). However, $\mathrm{MBr}$ is being phased out according to the Montreal Protocol, because it is an ozone-depleting molecule (Watson et al., 1992). During the last decade, various molecules have been proposed as $\mathrm{MBr}$ replacements to control soilborne diseases, nematodes, and weeds in polyethylene-mulched crops. Among those alternatives, the application of 1,3-D + Pic has been demonstrated to be an effective means to reduce the incidence of soilborne diseases in tomato (Lycopersicon esculentum) (Jones et al., 1995). De Cal et al. (2004), testing various alternatives to $\mathrm{MBr}$ in Spanish strawberry nurseries, found that Pic and 1,3-D were comparable to $\mathrm{MBr}$ for soilborne disease control. However, 1,3-D + Pic has weak activity against troublesome weeds, such as nutsedge (Noling and Gilreath, 2002).

Another molecule that has been indicated as a $\mathrm{MBr}$ alternative is $\mathrm{MNa}$, which is a broad-spectrum fumigant that upon soil application generates methyl isothiocyanate (Ajwa et al., 2003a). This fumigant has been tested in a variety of conditions with mixed results. Locascio et al. (1997) and Fennimore et al. (2003) suggested that $\mathrm{MNa}$ failed to reach the soilborne pest control levels of $\mathrm{MBr}+\mathrm{Pic}$, whereas other research has found that it can be a viable $\mathrm{MBr}$ alternative (Ajwa et al., 2003b). Despite these discrepancies, $\mathrm{MNa}$ is a relatively low-cost and versatile product that could be soil-sprayed or drip-applied, and further research is necessary to determine its efficacy in combination with other materials. The use of herbicides to complement the activity of $\mathrm{MBr}$ alternatives against weeds has been proposed for mulchedvegetable crops (Noling and Gilreath, 2002). The herbicide napropamide applied in preemergence is currently labeled for use in strawberry and pro-

\begin{tabular}{lllc}
\hline $\begin{array}{l}\text { Units } \\
\begin{array}{l}\text { To convert U.S. to SI, } \\
\text { multiply by }\end{array}\end{array}$ & U.S. unit & SI unit & $\begin{array}{l}\text { To convert SI to U.S., } \\
\text { multiply by }\end{array}$ \\
\hline 29.5735 & $\mathrm{fl} \mathrm{oz}$ & $\mathrm{mL}$ & 0.0338 \\
0.3048 & $\mathrm{ft}$ & $\mathrm{m}$ & 3.2808 \\
0.0929 & $\mathrm{ft}^{2}$ & $\mathrm{~m}^{2}$ & 10.7639 \\
3.7854 & gal & $\mathrm{L}$ & 0.2642 \\
9.3540 & gal/acre & $\mathrm{L} \cdot \mathrm{ha}^{-1}$ & 0.1069 \\
2.54 & inch(es) & $\mathrm{cm}^{3}$ & 0.3937 \\
16.3871 & inch & $\mathrm{cm}^{3}$ & 0.0610 \\
1.1209 & $\mathrm{lb} / \mathrm{acre}$ & $\mathrm{kg} \cdot \mathrm{ha}^{-1}$ & 0.8922 \\
0.0254 & $\mathrm{mil}$ & $\mathrm{mm}$ & 39.3701 \\
28.3495 & $\mathrm{oz}$ & $\mathrm{g}$ & 0.0353 \\
6.8948 & $\mathrm{psi}$ & $\mathrm{kPa}$ & 0.1450 \\
2.2417 & ton/acre & $\mathrm{t} \cdot \mathrm{ha}^{-1}$ & 0.4461 \\
\end{tabular}


vides acceptable to excellent control of most grasses and several broadleaf weeds (Stall, 2004; United Phosphorus, 2004). In strawberry, studies are needed to examine the effect of the previously mentioned $\mathrm{MBr}$ alternatives in combination with napropamide on soilborne pest control.

It is widely known that plants with vigorous roots can resist more readily soilborne disease and nematode infections, as well as weed competition for space, nutrients, and water. Strawberries are usually established from either bare-root or containerized (plug) transplants (Simonne et al., 2003). Bare-root plants are obtained from open-field nurseries, where stolons from mature plants are allowed to produce roots and establish in the soil. These new plants are then removed and shipped to planting fields. In contrast, plug nurseries utilize rooted stolons, which are transplanted in multicell trays and grown in greenhouses. This system for producing transplants results in plants with different root biomass and architecture, which have an influence on early plant establishment (Poling, 2003).

It has been hypothesized that because of their highly developed rooting system, containerized strawberry transplants could be less susceptible to soilborne pest damage (Burelle, 2003). Durner etal. (2002) and Poling (2003) outlined some of the advantages of plug transplants over bare-root plants, such as greater grower control of transplanting dates, improved plant survival and water management, and earlier flowering and fruit setting. Other studies have indicated that plug transplants resulted in faster root growth and establishment, earlier yields, and higher total yields than bare-root transplants (Burelle, 2003; Sances, 2000). Diverse reports have shown that although containerized transplants may have higher early marketable yield than bare-root plants, there is no difference in total marketable yield between both transplant types (Duval et al., 2004; Hochmuth et al., 2001; Poling, 2003). The combined effect of $\mathrm{MBr}$ alternatives and transplant type on soilborne pest control and strawberry fruit production has not been studied. This type of research could help researchers to devise new soilborne pest management strategies. Therefore, the objectives of this study were to: 1) compare the performance of two transplant systems under diverse $\mathrm{MBr}$ alternative programs in strawberry, and 2) determine the efficacy of these treatments on soilborne pest control in strawberry.

\section{Materials and methods}

Two field trials were conducted in three locations of west-central, northcentral, and northern Florida during the 1998-99 and 1999-2000 winter strawberry seasons. In west-central Florida, the experimental plots were established at the Gulf Coast Research and Education Center of the University of Florida in Bradenton, where soils are classified as EauGallie fine sand (Alfic Haplaquod). In north-central Florida, the study was conducted at the Horticultural Research Unit of the University of Florida in Gainesville, where soils are classified as Arredondo fine sand (Grossarenic Paleudult), whereas the soil at the North Florida Research and Education Center of the University of Florida in Quincy is Dothan sandy loam (Plinthic Kandiudult).

The experimental sites have a history of moderate to heavy nutsedge and nematode infestations, which can severely limit crop yield when they are not controlled. In all three locations, 12 treatments were distributed in a split-plot design with five replications in Gainesville and Quincy, and six replications in Bradenton. Fumigant treatments were: 1) nonfumigated control, 2) $\mathrm{MBr}+\operatorname{Pic}(67: 33$, by weight $)$ at $350 \mathrm{lb} /$ acre and napropamide at $4 \mathrm{lb} /$ acre, 3 ) Pic at $300 \mathrm{lb} /$ acre and napropamide at $4 \mathrm{lb} / \mathrm{acre}, 4) \mathrm{l}, 3-\mathrm{D}+$ Pic (65:35, by volume) at $35 \mathrm{gal} / \mathrm{acre}$ and napropamide at $4 \mathrm{lb} / \mathrm{acre}, 5$ ) $\mathrm{MNa}$ at $60 \mathrm{gal} / \mathrm{acre}$ and napropamide at $4 \mathrm{lb} / \mathrm{acre}$, and 6) $\mathrm{MNa}$ followed by $1,3-\mathrm{D}$ at 60 and $12 \mathrm{gal} /$ acre and napropamide at $4 \mathrm{lb} /$ acre, respectively. 'Chandler' strawberry transplants were either bare-root or plug plants, which were approximately 10 inches tall and were purchased from a commercial strawberry nursery in North Carolina. Fumigants were injected in the main plots to facilitate uniformity of application on each experimental unit, whereas transplant types were distributed in the subplots.

One day prior to fumigation, all treatment beds, except the nontreated control and $\mathrm{MBr}+\mathrm{Pic}$, were applied with the herbicide napropamide in preemergence at a labeled rate of 4 $\mathrm{lb} /$ acre to reduce weedy grass popula- tions (United Phosphorus, 2004). In Bradenton, napropamide was sprayed on bed tops with a tractor-mounted three-nozzle boom equipped with 11004 flat-fan nozzles (Spraying Systems Co., Wheaton, Ill.), calibrated to deliver $55 \mathrm{gal} / \mathrm{acre}$, and the application lines were pressurized with carbon dioxide at 30 psi. In Gainesville and Quincy, the herbicide application was accomplished with a backpack sprayer equipped with an 8004 flat-fan nozzle (Spraying Systems Co.) and calibrated to deliver $30 \mathrm{gal} / \mathrm{acre}$ at $32 \mathrm{psi}$. The fumigant $\mathrm{MNa}$ was tractor-applied with similar equipment as for napropamide application, with application lines calibrated to deliver $150 \mathrm{gal} / \mathrm{acre}$ at 30 psi. Immediately after application, MNa was incorporated between 4 and 6 inches deep with a rototiller. The fumigants $\mathrm{MBr}+\mathrm{Pic}$, Pic, 1,3-D + Pic, and $1,3-\mathrm{D}$ were injected between 6 to 8 inches deep into the finished bed using a $\mathrm{N}$-propelled fumigation rig with two (Gainesville and Quincy) and three (Bradenton) chisels per bed. This application occurred between 3 and 4 weeks before transplanting. Each chisel was spaced 6 inches (Bradenton) and 8 inches (Gainesville and Quincy) apart. Fumigant delivery was controlled by a flow meter that was calibrated to deliver the specified quantity of fumigant.

In Gainesville and Quincy, 500 $\mathrm{lb} /$ acre of $10 \mathrm{~N}-4.4 \mathrm{P}-8.3 \mathrm{~K}$ were applied as starter fertilizer, whereas 200 $\mathrm{lb} /$ acre of $15 \mathrm{~N}-0 \mathrm{P}-24.9 \mathrm{~K}$ were used in Bradenton. The fertilizer was applied on the same day as fumigation and was incorporated within the top 6 inches of the soil using a rototiller. Immediately after fertilizer incorporation, beds were pressed and a single drip irrigation line $(0.45 \mathrm{gal} / \mathrm{min}$ per $100-\mathrm{ft}$ row $)$ and black low-density polyethylene film (1.25 mil thick) were placed on bed tops. Approximately 3 weeks after treatment (WAT), double rows of strawberry plants were transplanted on 28-inch-wide beds, and between- and in-row spacing was 12 inches. Within 1 $\mathrm{h}$ after transplanting, the experimental sites were sprinkler-irrigated between 6 and 8 h per day for approximately 2 weeks. This procedure helps to provide enough moisture to the soil through the planting holes and row middles to ensure proper transplant establishment. In Gainesville and Quincy, experimental units were $18 \mathrm{ft}$ long $\left(42 \mathrm{ft}^{2}\right)$, whereas plots in Bradenton were $20 \mathrm{ft}$ long $\left(47 \mathrm{ft}^{2}\right)$. Irrigation, 
drip fertilization, frost protection, and insecticide and fungicide applications followed recommended commercial practices for Florida strawberry production (Simonne et al., 2003).

Nutsedge populations were assessed by counting the number of plants emerged through the polyethylene mulch. In Gainesville, this variable was determined at 3 and 10 WAT during the 1998-99 and 1999-2000 seasons. In Bradenton, nutsedge counts were obtained at 10 and 22 WAT in 1998-99 and at 8 and 22 WAT in 1999-2000. Nematode populations were determined between 20 and 22 WAT by extracting soil samples with a soil probe ( 1 inch wide $\times 8$ inches deep) from the rhizosphere of 20 strawberry plants per plot, and the nematodes were separated and counted from $100 \mathrm{~cm}^{3}$ soil using a standard sieving and centrifugation procedure (Jenkins, 1964). Although weed and nematode populations appeared to be present, only strawberry plant vigor, root weight, and marketable yield were collected in Quincy.

During both planting seasons, strawberry plant vigor was estimated at 20,22, and 14 WAT in Bradenton, Gainesville, and Quincy, respectively. Plant vigor was determined using a scale from $0 \%$ to $100 \%$, where $0 \%$ equals plant death and $100 \%$ indicates optimum growth. The latter was defined as strawberry plants with fully developed foliage, flowers, and fruits according to their vegetative stage, and free of leaf deformations, chlorosis, or damage. To assess plant vigor, treatments were compared within each replication. At the end of each season, the 10 central plants within each plot were excavated and their roots were shaken to remove soil from their surface. Within $10 \mathrm{~min}$, roots were weighted and averaged to obtain root weight per plant. Marketable fruit weight was collected twice per week, resulting in between 18 and 26 harvests in each location per planting season. Fruit harvests began approximately 7 weeks after transplanting. Early fruit yield was determined by adding the marketable fruit weights from all the December and January harvests.

Plant vigor values were expressed as percentages and transformed with arc sine square root prior to analysis of variance to normalize the treatment means, whereas the ranked means of the nutsedge and nematode populations were examined with Friedman's nonparametric test (Berenson and Levine, 1992; Howell, 1992). The significance of the main effects and the interaction between both factors on root weight per plant and marketable fruit weight were examined with analysis of variance. When significant differences were obtained, treatment means were separated with the Waller-Duncan multiple comparison procedure (SAS version 8; SAS Institute Inc., Cary, N.C.).

\section{Results and discussion}

There was significant treatment by location interaction for strawberry plant vigor, root weight, and early and total marketable fruit weight. Therefore, data from each location will be discussed separately. On the other hand, the planting season by treatment interaction was nonsignificant; thus data from both seasons within each location were combined for analysis and discussion. For strawberry plant vigor and root weight per plant, there were no significant fumigant by transplant type interactions. The lowest strawberry plant vigor was observed in the nonfumigated plots in all three locations, with $74 \%, 79 \%$, and $73 \%$ in Bradenton, Gainesville, and Quincy, respectively, whereas most treatments responded to fumigation by increasing vigor (Table 1). Particularly in Bradenton and Gainesville, plant vigor in fumigated plots was $\geq 86 \%$, respectively, regardless of the fumigant treatment. In Quincy, Pic and napropamide, and 1,3-D + Pic and napropamide had similar plant vigor as $\mathrm{MBr}+\mathrm{Pic}$, ranging between $76 \%$ and $80 \%$, while other treatments had the same plant vigor as the nontreated control. With regard to the transplant type, bare-root transplants had similar plant vigor as containerized-plug plants in two of the three locations (Table $\mathrm{l}$ ).

At all three locations, soil fumigation influenced strawberry root

Table 1. Influence of soil fumigants and type of transplant on strawberry plant vigor and root weight per plant at Bradenton, Gainesville, and Quincy, Fla., in 1998-99 and 1999-2000.

\begin{tabular}{|c|c|c|c|c|c|c|c|}
\hline \multirow[b]{2}{*}{ Fumigants ${ }^{\mathrm{z}}$} & \multirow{2}{*}{$\begin{array}{c}\text { Rate }^{\mathrm{y}} \\
\text { (unit/acre) }\end{array}$} & \multicolumn{3}{|c|}{ Plant vigor ${ }^{\mathrm{x}}$} & \multicolumn{3}{|c|}{ Root $w^{w}$} \\
\hline & & Bradenton & Gainesville & Quincy & Bradenton & Gainesville & Quincy \\
\hline $\mathrm{MBr}+\mathrm{Pic}$ & $350 \mathrm{lb}$ & $92 \mathrm{a}$ & $100 \mathrm{a}$ & $87 \mathrm{a}$ & $335 \mathrm{a}$ & 489 a & 229 a \\
\hline Pic + napropamide & $300 \mathrm{lb}+4 \mathrm{lb}$ & $86 a$ & $98 \mathrm{a}$ & $76 \mathrm{abc}$ & $250 \mathrm{ab}$ & $394 \mathrm{a}$ & $219 \mathrm{a}$ \\
\hline 1,3-D + Pic + napropamide & $35 \mathrm{gal}+4 \mathrm{lb}$ & 89 a & $91 \mathrm{a}$ & $80 \mathrm{ab}$ & $335 \mathrm{a}$ & $378 \mathrm{ab}$ & 229 a \\
\hline $\mathrm{MNa}+1,3-\mathrm{D}+$ napropamide & $60 \mathrm{gal}+12 \mathrm{gal}+4 \mathrm{lb}$ & 90 a & 98 a & $67 c$ & $255 \mathrm{ab}$ & $454 \mathrm{a}$ & $222 \mathrm{a}$ \\
\hline Significance & & * & * & * & * & * & * \\
\hline \multicolumn{8}{|l|}{ Transplant type } \\
\hline Bare root & --- & 88 & 94 & $86 a$ & $293 a$ & 377 & 210 \\
\hline Plugs & --- & 84 & 93 & $66 \mathrm{~b}$ & $244 \mathrm{~b}$ & 415 & 221 \\
\hline Significance & & NS & NS & * & * & NS & NS \\
\hline
\end{tabular}

${ }^{2} \mathrm{MBr}=$ methyl bromide; $\mathrm{Pic}=$ chloropicrin; $1,3-\mathrm{D}=1,3$-dichloropropene; $\mathrm{MNa}=$ metam sodium.

y l lb/acre $=1.1209 \mathrm{~kg} \cdot \mathrm{ha}^{-1} ; \mathrm{l} \mathrm{gal} /$ acre $=9.3540 \mathrm{~L} \cdot \mathrm{ha}^{-1} ; \mathrm{l} \mathrm{g}=0.0353 \mathrm{oz}$.

xPlant vigor obtained at 20,22, and 14 weeks after treatment in Bradenton, Gainesville, and Quincy, respectively. Data from two seasons were combined. Plant vigor values expressed as a percentage scale where $100 \%=$ optimum plant vigor and $0 \%=$ plant death. Data transformed with arc sine square root prior to analysis of variance (ANOVA) and treatment means were separated with Waller-Duncan multiple comparison procedure $(P \leq 0.05)$.

"Root weight per plant collected at the end of the strawberry season in each location. Data analyzed with ANOVA and treatment means were separated with Waller-Duncan multiple comparison procedure $(P \leq 0.05)$

ss, *Nonsignificant or significant at $P=0.05$, respectively. 
weight per plant, whereas in only one site (Bradenton) did the type of transplant have a significant effect on this variable (Table 1 ). In Bradenton, the average root mass per plant of the fumigated plots was $287 \mathrm{~g} /$ plant, which was more than twice that of the nontreated control (143 g/plant). A similar situation was observed in Quincy, where the fumigated plots had an average root weight of 222 $\mathrm{g} /$ plant, in contrast with only 180 $\mathrm{g} /$ plant in the nonfumigated control, which represented an approximately $20 \%$ increase. In Gainesville, only the plots treated with either $\mathrm{MBr}+\mathrm{Pic}$, Pic and napropamide, or $\mathrm{MNa}, 1,3-\mathrm{D}$ and napropamide were different from the control, having about 1.6 times more average root weight (446 g/plant) than the nonfumigated control (273 $\mathrm{g} /$ plant). In Bradenton, a 17\% root weight reduction was measured as transplant types changed from bareroot to containerized plugs.

Fumigant application influenced nutsedge densities in Bradenton and Gainesville, whereas no transplant type effect and transplant type by fumigant interaction were observed. Although the nutsedge pressure in these studies is considered low $\left(<13\right.$ plants $/ 10 \mathrm{ft}^{2}$ row) based on grower standards, the application of Pic and napropamide, 1,3-D + Pic and napropamide, $\mathrm{MNa}$ and napropamide, and $\mathrm{MNa}, 1,3-\mathrm{D}$ and napropamide provided similar nutsedge control as $\mathrm{MBr}+$ Pic. Ring nematode populations were affected only by fumigant application. In Bradenton, the nontreated control had the highest population (7.2 juve- niles $/ 100 \mathrm{~mL}$ ), while all the fumigants reduced the nematode counts to $<1$ juvenile/100 mL soil (Table 2). The nematode pressure was more intense in Gainesville, where the nontreated control had a root population of 24.5 juveniles/100 mL soil. There was no significant difference among all fumigants.

In Gainesville and Quincy, early strawberry yield was individually influenced by both factors, whereas in Bradenton only the fumigants had an effect on this variable. There was no significant fumigant by transplant type interaction at all three locations. In Gainesville, plug transplants had higher early yield than bare-root transplants, whereas the opposite occurred in Quincy (Table 3). At all experimental sites, the nonfumigated control had

Table 2. Influence of soil fumigants on ring nematode (Criconema spp.) and nutsedge (Cyperus spp.) populations in strawberry fields at Bradenton and Gainesville, Fla., in 1998-99 and 1999-2000.

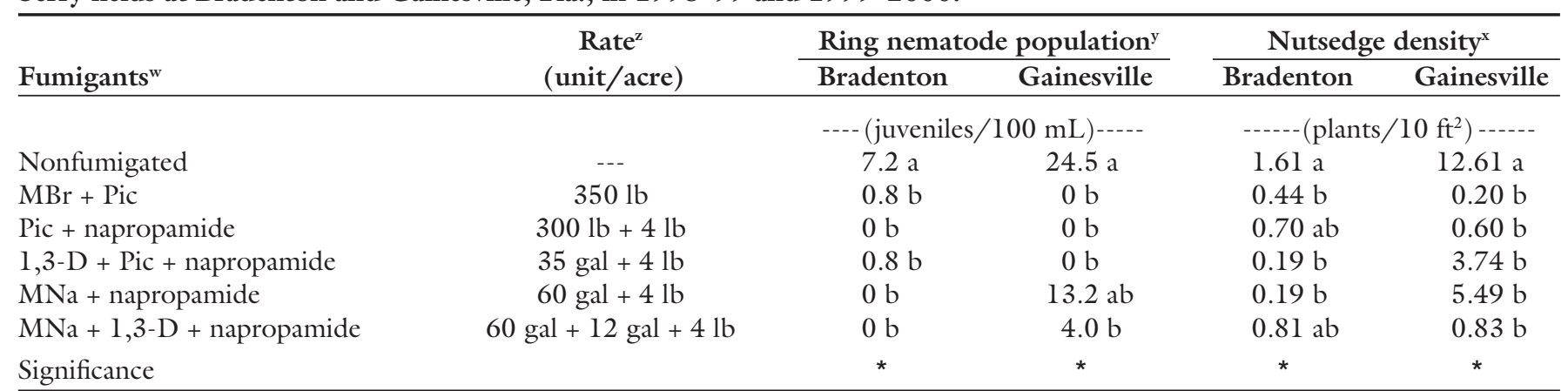

${ }^{2} 1 \mathrm{lb} /$ acre $=1.1209 \mathrm{~kg} \cdot \mathrm{ha}^{-1} ; \mathrm{l}$ gal $/$ acre $=9.3540 \mathrm{~L} \cdot \mathrm{ha}^{-1} ; \mathrm{l}$ juvenile $/ 100 \mathrm{~mL}=37.8541$ juveniles $/ \mathrm{gal} ; \mathrm{l} \mathrm{plant} / 10 \mathrm{ft}{ }^{2}=1.0764 \mathrm{plant} / \mathrm{m}^{2}$.

yematode populations obtained between 20 and 22 weeks after treatment. Data from two seasons were combined. Data analyzed with Friedman's nonparametric test and treatment means were separated with Waller-Duncan multiple comparison procedure $(P \leq 0.05)$.

${ }^{x}$ Nutsedge densities collected at 22 and 10 weeks after treatment in Bradenton and Gainesville, respectively. Data from two seasons were combined. Data analyzed with Friedman's nonparametric test and treatment means were separated with Waller-Duncan multiple comparison procedure $(P \leq 0.05)$.

${ }^{\mathrm{w}} \mathrm{MBr}=$ methyl bromide; $\mathrm{Pic}=$ chloropicrin; $1,3-\mathrm{D}=1,3$-dichloropropene; $\mathrm{MNa}=$ metam sodium.

"Significant at $P=0.05$.

Table 3. Influence of soil fumigants and type of transplant on early and total marketable strawberry yield at Bradenton, Gainesville, and Quincy, Fla., in 1998-99 and 1999-2000.

\begin{tabular}{|c|c|c|c|c|c|c|c|}
\hline \multirow[b]{3}{*}{ Fumigants $^{\mathrm{z}}$} & \multirow{3}{*}{$\begin{array}{c}\text { Rate }^{\mathrm{y}} \\
\text { (unit/acre) }\end{array}$} & \multicolumn{6}{|c|}{ Marketable fruit wt } \\
\hline & & \multicolumn{3}{|c|}{ Total yield } & \multicolumn{3}{|c|}{ Early yield } \\
\hline & & Bradenton & Gainesville & Quincy & Bradenton & Gainesville & Quincy \\
\hline & $\ldots$ & $20 \mathrm{~b}$ & $10 \mathrm{~b}$ & $20 \mathrm{~b}$ & $145 \mathrm{~b}$ & & \\
\hline $\begin{array}{l}\text { Nonfumigated } \\
\mathrm{MBr}+\mathrm{Pic}\end{array}$ & $350 \mathrm{lb}$ & $\begin{array}{l}3.0 \mathrm{~b} \\
3.5 \mathrm{a}\end{array}$ & $\begin{array}{l}1.9 \mathrm{~b} \\
40 \mathrm{a}\end{array}$ & $\begin{array}{l}3.0 \mathrm{~b} \\
4.0 \mathrm{a}\end{array}$ & $\begin{array}{l}14.5 \mathrm{~b} \\
187 \mathrm{a}\end{array}$ & $\begin{array}{l}12.1 \mathrm{~b} \\
217 \mathrm{a}\end{array}$ & $12.7 \mathrm{~b}$ \\
\hline Pic + napropamide & $300 \mathrm{lb}+4 \mathrm{lb}$ & $3.5 \mathrm{a}$ & $3.5 \mathrm{a}$ & $3.6 \mathrm{a}$ & $18.1 \mathrm{a}$ & $19.1 \mathrm{a}$ & $14.7 \mathrm{a}$ \\
\hline $\mathrm{MNa}+$ napropamide & $60 \mathrm{gal}+4 \mathrm{lb}$ & $3.4 \mathrm{a}$ & $3.1 \mathrm{a}$ & $3.7 \mathrm{a}$ & $16.9 \mathrm{a}$ & $20.3 \mathrm{a}$ & $14.2 \mathrm{a}$ \\
\hline $\mathrm{MNa}+1,3-\mathrm{D}+$ napropamide & $60 \mathrm{gal}+12 \mathrm{gal}+4 \mathrm{lb}$ & $3.6 \mathrm{a}$ & $3.3 \mathrm{a}$ & $3.5 \mathrm{a}$ & $18.1 \mathrm{a}$ & $21.4 \mathrm{a}$ & $14.6 \mathrm{a}$ \\
\hline Significance & & * & * & * & * & * & * \\
\hline \multicolumn{8}{|l|}{ Transplant type } \\
\hline Bare root & --- & 3.3 & $2.8 \mathrm{~b}$ & $3.8 \mathrm{a}$ & 17.6 & 19.2 & 14.2 \\
\hline
\end{tabular}

${ }^{2} \mathrm{MBr}=$ methyl bromide; $\mathrm{Pic}=$ chloropicrin; $1,3-\mathrm{D}=1,3$-dichloropropene; $\mathrm{MNa}=$ metam sodium.

y $1 \mathrm{lb} /$ acre $=1.1209 \mathrm{~kg} \cdot \mathrm{ha}^{-1} ; \mathrm{l}$ gal $/$ acre $=9.3540 \mathrm{~L} \cdot \mathrm{ha}^{-1} ; \mathrm{l}$ ton $/$ acre $=2.2417 \mathrm{t} \cdot \mathrm{ha}^{-1}$.

Ns, *Nonsignificant of significant at $P=0.05$, respectively. 
lower early strawberry yield than any of the fumigant treatments. For total marketable yield, fumigation increased marketable strawberry yield in all three locations, but neither transplant type nor the interaction between both factors had any effect on total fruit weight (Table 3 ). Total marketable yield improved by $24 \%, 69 \%$, and $16 \%$ with fumigation in Bradenton, Gainesville, and Quincy, respectively.

In summary, nutsedge and ring nematode infestations appeared to be major factors reducing strawberry yield, and they were effectively controlled by all the fumigants tested in this study. These results showed that under the conditions of these studies, bare-root transplants produce strawberry plants with equal or higher vigor and root biomass than containerized plugs, which could be due to the different root architectures of the types of transplants. Although transplant type had an effect on early strawberry yield, the results were inconsistent across locations. At the same time, the increase in root biomass and vigor did not translate into higher total marketable yield or improved fumigant performance against ring nematode and nutsedge. This finding does not agree with previous reports, which established that containerized transplants might improve soilborne pest control with MBr alternatives (Burelle, 2003). Nonetheless, these results consistently confirm other studies, which indicated that there was no total marketable yield difference between the two strawberry transplant types (Duval, 2004; Hochmuth et al., 2001; Poling, 2003).

\section{Literature cited}

Ajwa, H.A., S.D. Nelson, and T. Trout. 2003a. Water and methyl isothiocyanate distribution in soil after drip fumigation with metam sodium. Proc. Annu. Intl. Res. Conf. Methyl Bromide Alternatives and Emissions Reduction, Paper 37, p. 1-2.
Ajwa, H.A., S. Fennimore, Z. Kabir, F. Martin, J. Duniway, G. Browne, T. Trout, R. Goodhue, and L. Guerrero. 2003b. Strawberry yield under reduced application rates of chloropicrin and inline in combination with metam sodium and VIF. Proc. Annu. Intl. Res. Conf. Methyl Bromide Alternatives and Emissions Reduction, Paper 3, p. 1-2.

Berenson, M.L. and D.M. Levine. 1992. Basic business statistics: Concepts and applications. Prentice Hall, Englewood Cliffs, N.J.

Burelle, N.K. 2003. Effects of transplant type and soil fumigant on growth and yield of strawberry in Florida. Plant Soil J. 256:273-280.

De Cal, A., A. Martínez-Treceño, J.M. López-Aranda, and P. Melgarejo. 2004. Chemical alternatives to methyl bromide in Spanish strawberry nurseries. Plant Dis. 88:210-214.

Durner, E.F., E.B. Poling, and J.L. Maas. 2002. Recent advances in strawberry plug transplant technology. HortTechnology 12:545-550.

Duval, J.R., C.K. Chandler, and E. Golden. 2004. Planting date affects early season fruit yield of strawberry in a subtropical environment. Vegetarian Nwsl. 04-01:1-3.

Fennimore, S.A., M.J. Haar, and H.A. Ajwa. 2003. Weed control in strawberry provided by shank- and drip-applied methyl bromide alternative programs. HortScience 38:55-61.

Hochmuth, G., C. Chandler, S. Stanley, D. Legard, J. Duval, E. Waldo, D. Cantliffe, T. Crocker, and E. Bish. 2001. Containerized transplants for establishing strawberry crops in Florida. HortScience 36:443. (Abstr.).

Howell, D.C. 1992. Statistical methods for psychology. Duxbury Press, Boston.

Jenkins, W.R. 1964. A rapid centrifugal-flotation technique for separating nematodes from soil. Plant Dis. Rptr. 48:692.

Jones, J.P., J.P. Gilreath, and A.J. Overman. 1995. Control of soil-borne disease of mulched tomato by fumigation. Proc. Fla. State Hort. Soc. 108:201-203.
Locascio, S.J., J.P. Gilreath, D.W. Dickson, T.A. Kucharek, J.P. Jones, and J.W. Noling. 1997. Fumigant alternatives to methyl bromide for polyethylene-mulched tomato. HortScience 32:1208-1211.

Noling, J.W. and J.P. Gilreath. 2002. Field scale demonstration/validation studies of alternatives for methyl bromide in plastic mulch culture in Florida. Citrus Veg. Mag. 67(4):18-31.

Poling, E.B. 2003. Strawberry plasticulture: A possibility for local growers, p. 11-17. In: N.F. Childers (ed.). The strawberry, A book for growers, others. E.O. Painter, De Leon Springs, Fla.

Sances, F.V. 2000. Conventional and organic alternatives to methyl bromide on California strawberries. Proc. Annu. Intl. Res. Conf. Methyl Bromide Alternatives and Emissions Reduction, Paper 24, p. 1-3.

Simonne, E.H., G.J. Hochmuth, W.M. Stall, J.R. Duval, T.A. Kucharek, J.F. Price, T.G. Taylor, and S.A. Smith. 2003. Strawberry production in Florida, p. 251-263. In: S.O. Olson and E.H. Simonne (eds.). Vegetable production guide for Florida, 2003-04. IFAS Publ., Univ. of Florida, Gainesville, Fla.

Stall, W.M. 2004. Weed management, p. 79-84. In: S.O. Olson and E.H. Simonne (eds.). Vegetable production guide for Florida, 2003-04. IFAS Publ., Univ. of Florida, Gainesville, Fla.

United Phosphorus. 2004. Devrinol 2EC. 29 Oct. 2005. <http://www.upi-usa. com/files/Devrinol\%202EC\%20Specimen \%20Rev\%208-04.pdf>.

U.S. Department of Agriculture. 2005. Statistics of vegetables and melons. 14 Feb. 2006. <http://www.usda.gov/nass/ pubs/agr05/05_ch4.PDF $>$.

Watson, R.T., D.T. Albritton, S.O. Anderson, and S. Lee-Bapty. 1992. Methyl bromide: Its atmospheric science, technology and economics. Montreal Protocol Assessment Suppl. United Nations Environ. Programme. Nairobi, Kenya. 